\title{
Antimicrobial Activity of Leave Extracts of Bryophyllum pinnatum and Aspilia africana on Pathogenic Wound Isolates Recovered from Patients Admitted in University of Port Harcourt Teaching Hospital, Nigeria
}

\author{
Azuonwu Obioma1 ${ }^{1 *}$, Azuonwu Testimonies Chikanka ${ }^{2}$ and Ibulubo Dumo ${ }^{1}$ \\ ${ }^{1}$ Department of Medical Laboratory Science, Faculty of Sciences, Rivers State University, Nkpolu, Port, Harcourt, Nigeria \\ ${ }^{2}$ Department of Microbiology, Faculty of Sciences, Rivers State University, Nkpolu, Port, Harcourt, Nigeria
}

${ }^{*}$ Corresponding author: Azuonwu Obioma, Department of Medical Laboratory Science, Faculty of Sciences, Rivers State University, Nkpolu, Port, Harcourt, Nigeria Tel: +234 8035519688; E-mail: bimajacobs@yahoo.co.uk.

Received: July 05, 2017; Accepted: July 26, 2017; Published: August 05, 2017

Citation: Obioma A, Chikanka AT, Dumo I (2017) Antimicrobial Activity of Leave Extracts of Bryophyllum pinnatum and Aspilia africana on Pathogenic Wound Isolates Recovered from Patients Admitted in University of Port Harcourt Teaching Hospital, Nigeria. Ann Clin Lab Res Vol. 5:No.3:185

\section{Abstract}

The incidence of antibiotic resistance among bacteria to synthetic drugs is on the increase, as such there is the need for new and safer antimicrobials especially, from natural sources like plants. Leaves of Bryophyllum pinnatum and Aspilia africana are among the many that have been used by rural dwellers as medicines to treat infections. Methanol, hot water and ethanolic extracts of the leaves of Bryophyllum pinnatum and Aspilia africana were obtained and their antimicrobial activity testing against three microorganisms isolated from wound which includes Staphylococcus aureus, Escherichia coli and Pseudomonas aeruginosa. The results indicated that the methanol extract of both plants had higher antimicrobial activity against the test isolates as compared with their ethanol extracts; while the hot water extracts had no antimicrobial activity against the isolates. Ethanol extracts of both plants showed little antimicrobial activity against the test isolates. S. aureus was more susceptible to methanolic extract of $B$. pinnatum with a zone of inhibition of $4 \mathrm{~mm}, E$. coli was $3.0 \mathrm{~mm}$ while that of $P$. aeruginosa was $1.0 \mathrm{~mm}$. Susceptibility pattern of the isolates to $A$. africana showed that $P$. aeruginosa was more susceptible with a zone of inhibition of $6.0 \mathrm{~mm}$; that of $S$. aureus was $5.0 \mathrm{~mm}$ while that of $E$. coli was $3.0 \mathrm{~mm}$. This shows that methanolic extracts of Bryophyllum pinnatum and Aspilia africana can be used against pathogenic organisms including Staphylococcus aureus, Escherichia coli and Pseudomonas aeruginosa which can cause slow healing of wounds.

Keywords: Wounds; Methanolic extract; Antimicrobial activity; Bryophyllum pinnatum, Aspilia Africana, Port Harcourt

\section{Introduction}

The colonization of wounds by microorganisms is an important cause of death among surgical patients. When there is a hole in the skin, microorganisms (more often the opportunistic ones) invade and multiply in the hole causing delay in the wound healing and as such an infection which can lead to asymptomatic colonization, bacteremia or even death [1]. Microorganisms frequently isolated from wounds include those of the genera Pseudomonas, Candida, Staphylococcus, Streptococcus, Bacillus and even Escherichia coli. The higher frequency associated with these organisms is their ability to form biofilms on colonized surfaces thus aiding in their resistance to antibiotics and virulence [2]. Proper sanitation of wounds and good hygiene practices can avoid complications arising from the colonization of some fungi and bacteria on wounds $[3,4]$.

Substances that are able to kill bacteria are generally referred as antibiotics. They can be applied on the skin, taken intravenously or taken in orally (through the mouth). They may be in liquid form or powdered form. With the recent emergence and re-emergence of antibiotic resistance as a result of widespread use of antibiotics, this has become a public health issue worldwide and has been documented $[5,6]$. This emergence of antibiotic resistance has also been linked with the wrong use of antibiotics [7]. A good number of persons living in underdeveloped and some developing countries survive below the poverty line, are unable to afford proper medical care and as such rely on patent medicine stores whenever they fall sick. This has led to continual abuse of drugs especially antibiotics as most times, broad spectrum antibiotics are prescribed and misused. In other cases when the right drugs are prescribed, most patients either do not complete the dosage especially if they begin to notice improvement in their health or do not take the drugs at the appropriate time. Subsequently, these make the microorganism resistant to these drugs when they are taken. There is therefore, the need to explore new and safer antimicrobials that can probably act in a manner different from the already existing ones [8]. This has led to research into 
the use of whole or parts of plants with the purpose of exploring the active ingredient that can be used in the production of new antimicrobial drugs $[9,10]$. This is of advantage since the plants are cheaper, most of which can be found in our environment and as such, a great breakthrough in modern medicine [11].

Plants are free gifts of nature and are found around us. Although some plants are prevalent in some areas, if the environmental conditions are favourable, they can be transplanted to another habitat. Most plants are not just sources of food, but are used as herbs and as such are medicinal. Different parts (bark, root, twig, fruit and leaves) of different plants have been studied and found to be sources of antimicrobial agents. These include Moringa oliefera, Jatropha curcas, Carica papaya, Psidium guajava, Magnifera indica and others [12-14]. Moringa oliefera has been reported to possess antitumoural, antioxidant, anti-inflammatory, hypoglycaemic and antimicrobial properties [15]. Jatropha curcas over the years have been reported to possess bioactive activity against guinea worm sores, fever, joint rheumatism, jaundice and mouth infections [13]

Bryophyllum pinnatum (Lam.) Oken, is an environmental weed from the family Crassulceae that is most often used to treat urinary stones, hypertension, cold, abscesses, asthma, insect bite, skin disorders and other ailments. It is a succulent glabrous herb that is $0.3 \mathrm{~m}-1.2 \mathrm{~m}$ high. It is native to Madagascar and Southern Africa and grows mainly in the tropics [16]. It is commonly called air plant, life plant, love plant or miracle leaf [17]. Aspilia africana on the other hand, is a semi-woody herb that grows up to $2 \mathrm{~m}$ high and occurs throughout tropical Africa and the wasteland of the Savannah forest. The mashed leaves and flowers are used in treating sores and wounds and can stop bleeding. Ugandans use the leaf extract to treat gonorrhea, Ghanaians use the leaves to prepare cough medicine for kids; while in Tangayika, its root extract is used to treat tuberculosis $[18,19]$. Its methanol extract has been found to possess antiulcer activity while its hexane extract has been reported to possess antiinflammatory activity $[20,21]$. It has also been found to be useful in the treatment of diseases affecting the urinary organs without adverse side effects [16]. Highlighting the increase in the incidence of antibiotic resistance which has become a public concern, newer and safer antibiotics need to be introduced of which some plants have been found to be effective. This study is aimed at testing the antimicrobial effect of Bryophyllum pinnatum and Aspilia africana on isolates from wounds, thus their possible use for the synthesis of antimicrobial drugs.

\section{Methodology}

\section{Collection of bacterial isolates}

The bacterial isolates used in this study had been isolated from wounds and were obtained from the microbiology laboratory of the University of Port Harcourt Teaching Hospital.
The isolates were Pseudomonas aeruginosa, Escherichia coli and Staphylococcus aureus.

\section{Identification of isolates}

The collected isolates were sub cultured in Nutrient Agar (CM0003, Oxoid UK) and then identified using standard microbiological procedures by carrying out gram's reaction and biochemical tests to confirm the species [22]. The identified isolates were suspended in nutrient agar slants and were subsequently used in testing the extracts respectively.

\section{Collection of the leaves}

The leaves of Bryophyllum pinnatum and Aspilia africana which were identified by a botanist in the Department of Medical Laboratory Science of the Rivers State University of Science and Technology, Port Harcourt, Nigeria. Nonetheless, the leaves were collected from the garden and premises of the Rivers State University of Science and Technology, Port Harcourt and were therefore transported to the laboratory immediately for processing. The leaves were washed using tap water to remove dust and then dried in the oven at $37^{\circ} \mathrm{C}$ for 3 days while the leaves of $A$. africana were dried at $70^{\circ} \mathrm{C}$ for 4 days. The difference in drying time and temperature was because of their varied thickness in architecture of the leaves.

\section{Preparation of extracts}

The dried leaves were blended differently using a sterile electric blender (rinsed with absolute alcohol) to fine powder. The leaves were not exposed to direct sunlight so that the active compounds are not lost [23]. The hot water (aqueous) extract was prepared by putting $10 \mathrm{~g}$ of each of the fine powder into a $100-\mathrm{ml}$ flask to which $10 \mathrm{ml}$ of distilled water was added. This was heated to boil for one hour using a hot plate and stirred regularly for 3 minutes to 5 minutes. After which, the mixture was filtered using Whatmann No 1 filter paper and the supernatant recovered. The methanol and ethanol extracts were prepared according to the method of Ekpe [24]. It was prepared in a ratio of 1:1 (10 g of the fine powder of each plant added to $10 \mathrm{ml}$ of methanol and ethanol each). The mixture was allowed to stand at room temperature for 4 hours with occasional stirring. The mixtures were after which filtered separately using Whatmann No 1 filter paper to remove the residue. The filtrate was allowed to settle for 30 minutes and then left to evaporate for two days at room temperature till it was concentrated. The concentrated aqueous, ethanol and methanol extracts were thereafter stored at $5^{\circ} \mathrm{C}$ in the refrigerator for use.

\section{Antibiotic discs}

Gram negative and gram positive multipurpose discs were used to compare the susceptibility pattern of the isolates to that of the plant extracts. This was done using the disc diffusion method. 


\section{Inoculum size}

Bacterial suspensions were made in sterile normal saline and adjusted to 0.5 Macfarland's standard which is $108 \mathrm{cfu} / \mathrm{ml}$ (NCCLS).

\section{Screening of plant extracts for antimicrobial activity}

This was done according to the method of Atata [25]. Each test microorganism was uniformly inoculated onto freshly prepared Mueller-Hinton Agar (Oxoid, UK) using a sterile cotton swab. A 5-mm diameter sterile cork borer was used to make wells in the medium; $0.1 \mathrm{~mL}$ of each of the extracts was then dropped in the holes and labeled accordingly. The control for each was prepared by adding ethanol and methanol separately to small pieces of cut filter paper and then seeded onto the inoculated agar plates. The setups were allowed to stand at room temperature for 30 minutes before being incubated at $37^{\circ} \mathrm{C}$ for 24 hours. After 24 hours, the zones of inhibition around each of the extracts was measured and recorded in millimeter.

\section{Data presentation}

The results obtained were represented using tables as shown below.

\section{Results}

Methanol, ethanol and hot water extracts from the leaves of Bryophyllum pinnatum and Aspilia africana were tested against different wound isolates. Results obtained as recorded in Table $\mathbf{1}$ and Table $\mathbf{2}$ indicates that the methanol extracts of both plants had a higher antimicrobial activity compared with their ethanol extracts, while the hot water extracts of both plants had no antimicrobial activity. Methanol extract of $A$. africana had the highest activity against Pseudomonas aeruginosa with a zone of inhibition of $6.0 \mathrm{~mm}$ while that of $B$. pinnatum was $1.0 \mathrm{~mm}$. Susceptibility of Staphylococcus aureus to methanolic extract of $A$. africana was high with a zone of inhibition of $5.0 \mathrm{~mm}$ while that of $B$. pinnatum was $4.0 \mathrm{~mm}$. Susceptibility of Escherichia coli to the methanol of both plants was the same with a zone of inhibition of $3.0 \mathrm{~mm}$. Ethanolic extract of $B$. pinnatum was less effective on the test isolates with all the isolates having a zone of inhibition of $1.0 \mathrm{~mm}$ while ethanolic extract of $A$. africana was more effective on $\mathrm{E}$. coli with a zone of inhibition of $3.0 \mathrm{~mm}$, on $P$. aeruginosa with a zone of inhibition of $1.0 \mathrm{~mm}$ but had no activity against $S$. aureus (Figure 1 and Figure 2).

Table 3 shows that $S$. aureus was more susceptible to chloramphenicol and lincocin with their zones of inhibition being $9.0 \mathrm{~mm}$. Rifampicin had the least antibiotic effect on $S$. aureus with a zone of inhibition of $6.0 \mathrm{~mm}$. The susceptibility pattern of E. coli to gram negative antibiotic discs indicated that it was most susceptible to ciprofloxacin with a zone of inhibition of $13 \mathrm{~mm}$ and it was least susceptible to Nalidixic acid and Streptomycin with zones of inhibition of $6 \mathrm{~mm}$ as recorded in Table 4.

Table 1 Antimicrobial activity of Bryophyllum pinnatum extracts with the zone of inhibition $(\mathrm{mm})$.

\begin{tabular}{|l|l|l|l|}
\hline Test organisms & $\begin{array}{l}\text { Neat } \\
\text { pinnatum } \\
\text { methanol } \\
\text { extract }\end{array}$ & $\begin{array}{l}\text { Neat B. } \\
\text { pinnatum hot } \\
\text { water } \\
\text { extract }\end{array}$ & $\begin{array}{l}\text { Neat } \\
\text { pinnatum } \\
\text { ethanol } \\
\text { extract }\end{array}$ \\
\hline $\begin{array}{l}\text { Staphylococcus } \\
\text { aureus }\end{array}$ & 4 & - & 1 \\
\hline Escherichia coli & 3 & - & 1 \\
\hline $\begin{array}{l}\text { Pseudomonas } \\
\text { aeruginosa }\end{array}$ & 1 & - & 1 \\
\hline \multicolumn{2}{|l}{$++=$ Moderately sensitive; +=Sensitive; -=Resistant } \\
\hline
\end{tabular}

Table 2 Antimicrobial activity of Aspilia Africana against the test isolates with the zone of inhibition $(\mathrm{mm})$.

\begin{tabular}{|c|c|c|c|}
\hline Test organisms & $\begin{array}{c}\text { Neat } A . \\
\text { africana } \\
\text { methanol } \\
\text { extract }\end{array}$ & $\begin{array}{c}\text { Neat } A . \\
\text { africana } \\
\text { hot water } \\
\text { extract }\end{array}$ & $\begin{array}{r}\text { Neat } A \text {. africana } \\
\text { ethanol extract }\end{array}$ \\
\hline $\begin{array}{c}\text { Staphylococcus } \\
\text { aureus }\end{array}$ & $++(5.0)$ & - & $-(0.0)$ \\
\hline $\begin{array}{c}\text { Escherichia coli } \\
\text { Pseudomonas } \\
\text { aeruginosa }\end{array}$ & $+(3.0)$ & - & $+(3.0)$ \\
\hline \multicolumn{2}{c|}{$+(6.0)$} & - & $+(1.0)$ \\
\hline \multicolumn{2}{|c|}{ Moderately sensitive; +=Sensitive; -=Resistant } \\
\hline
\end{tabular}

\section{Discussion}

The presence of Staphylococcus aureus, Escherichia coli and Pseudomonas aeruginosa in wounds is of public health concern as their presence can lead to serious complication of nosocomial infections if unchecked in good time [26], especially in cases where the wounds are not properly treated or just left open. These organisms are normally found in moist environments and only become pathogenic when they introduced to areas in the body that lack normal host defenses such as when the skin has an injury or direct tissue damage [27]. In this study, all three isolates were sensitive to ciprofloxacin. Extensive use of this antibiotic and other related ones has led to reported cases of multi-drug resistant plasmids and transposons found in strains of bacterial genera associated with nosocomial infections [28]. However, multidrug resistant saga has continued to pose critical health challenging issues especially in our remote villages with little or non-existence of functional health infrastructure to carter for increasing population of the citizens. Nonetheless, it may probably be believed that some of the reasons for the geometric increase of multi drug resistance cases might be linked to poor prescriptions expertise of antibiotic regimen and nonadherence to drug intake pattern recommendation by the subjects as suggested by the physician, even as it seems to be an evidence of lack of health awareness education on the 
subject matter among the subjects, in our remote communities.

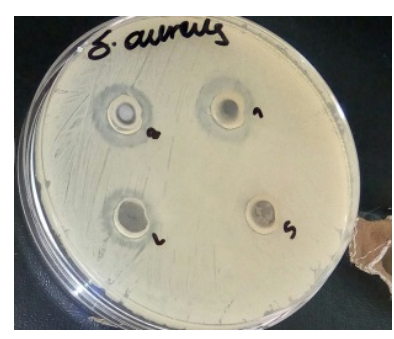

Figure 1 Zones of inhibition around neat $B$. pinnatum methanol extract against $S$. aureus.

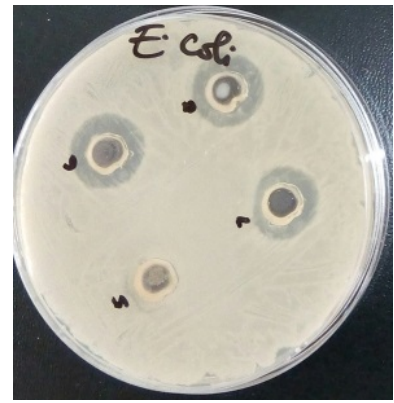

Figure 2 Zones of inhibition around neat $B$. pinnatum methanol extract against Escherichia coli.

Table 3 Antimicrobial sensitivity of Staphylococcus aureus to known antibiotics.

\begin{tabular}{|c|c|}
\hline Gram positive antibiotic disc & Zone of inhibition (mm) \\
\hline Ciprofloxacin (CPX) & $+(8.0)$ \\
\hline Norfloxacin (NB) & $+(7.0)$ \\
\hline Gentamicin (GN) & $+(8.0)$ \\
\hline Lincocin (LC) & $++(9.0)$ \\
\hline Streptomycin (S) & $+(7.0)$ \\
\hline Rifampicin (RD) & $+(6.0)$ \\
\hline Erythromycin (E) & $+(8.0)$ \\
\hline Chloramphenicol (CH) & $++(9.0)$ \\
\hline Ampiclox (APX) & $+(7.0)$ \\
\hline Floxapen (FLX) & $+(7.0)$ \\
\hline
\end{tabular}

The sensitivity of the test isolates to methanolic extracts of both plants is at variance with the findings of Obi and Onuoha [29], who described ethanol as the best solvent for the extraction of bioactive substances from plants. The ability of the methanolic extract of both plants to be more effective than that the ethanolic extract could be linked to the fact that, the active antimicrobial agent in the leaves are more soluble in methanol and as such, it is able to extract the antimicrobial contituents from the leaf [30]. The sensitivity of the $P$. aeruginosa to the methanolic extract of both leaves is in contrast to the study carried out by Faleye and Ogundaini [18], who reported that the Aspilia africana extracts obtained using six different solvents, had no activity on $P$. aeruginosa. This may be because the solvents used in the extraction process could not extract the active antimicrobial agent against $P$. aeruginosa.

Table 4 Antimicrobial Sensitivity of $E$. coli and $P$. aeruginosa to known antibiotics.

\begin{tabular}{|l|l|l|}
\hline $\begin{array}{l}\text { Gram negative antibiotic } \\
\text { disc }\end{array}$ & Escherichia coli & $\begin{array}{l}\text { Pseudomonas } \\
\text { aeruginosa }\end{array}$ \\
\hline Ciprofloxacin (CPX) & $+++(13.0)$ & $++(10.0)$ \\
\hline Gentamicin (CN) & $+(7.0)$ & $+(8.0)$ \\
\hline Streptomycin (S) & $+(6.0)$ & $+(7.0)$ \\
\hline Peflacine (PEF) & $+++(11.0)$ & $++(10.0)$ \\
\hline Augmentin (AU) & $++(9.0)$ & $++(9.0)$ \\
\hline Ceprorex (CEP) & $+(7.0)$ & $+(6.0)$ \\
\hline Nalidixic acid (NA) & $+(6.0)$ & -- \\
\hline Septrin (SXT) & $++(10.0)$ & $+(8.0)$ \\
\hline Ampicillin (PN) & $+(8.0)$ & -- \\
\hline Ofloxacin (OFX) & $++(10.0)$ & $++(12.0)$ \\
\hline Lincocin (LC) & -- & $+(8.0)$ \\
\hline Rifampicin (RD) & -- & $+(8.0)$ \\
\hline
\end{tabular}

Testing of the leaves of two the plants, Bryophyllum pinnatum and Aspilia africana, according to the results obtained above indicated that both plants had antimicrobial activity against Staphylococcus aureus, Escherichia coli and Pseudomonas aeruginosa at different levels. Although a previous study on its influence on the estrous cycle and histoarchitecture of the uterus of female rats suggested a negative influence on the reproductive health of the animal [31], modifications can be made during its processing, to make it safer for humans.

No doubt, the use of medicinal plants has been helpful in the treatment of wounds, cough and many other illnesses in our rural communities by our great grandfathers and ancestors. However, some of the conventional methods of extractions are through maceration and soxhlet extraction, though one critical challenge of these methods is that it does not give room to large quantity of the extracts to be explored for commercial use. These tend to limit the widely application of these important natural resources in the local communities. Nonetheless, critical improvements have been made, through the use of Ultrasound Assisted Extraction (UAE), Micro Wave Assisted (MAE), and Supercritical Fluid Extraction (SFE) which have certainly improved the extraction process of the medicinal plant. However, one significant setback on the use of improved methods of extraction in our local communities would anchor strongly on the lack of expertise and professional skills, lack of power (Electricity) and weak 
infrastructural developments, in our developing communities to stimulate large productions of these medicinal plants to be available at all times for the treatment of emerging and reemerging of infectious diseases across the globe, especially in this period of increasing trend of antibiotic resistant saga. Furthermore, the measurement and determination of the actual doses of the medicinal plants have also provoked massive challenges to the traditional herbal doctors during the prescription and treatment of their patients in our rural villages. Thus, the need to create enabling grounds that would promote the mass production of the medicinal plants with minimal cost cannot be over emphasized, since it has already been proven to possess rich therapeutic attributes as an alternative option to synthetic commercially prepared medicines (drugs). It is strongly believed that, the promotion of the use of medicinal plants would help to reduce the increasing statistic of antibiotic resistance crises in our various hospitals and health centers globally.

\section{Conclusion}

In conclusion, the leaves of Bryophyllum pinnatum and Aspilia africana possess antimicrobial properties and as such can be harnessed for the production of antimicrobial drugs. Indiscriminate use of drugs, especially antibiotics should be discouraged; sick persons should be encouraged to visit a physician in a hospital/clinic, run specific tests, drugs administered based on the test result and the dosage of the drugs should be completed. Mass campaigns should be carried out to sensitize the public on the increasing trend of antibiotic drug resistance, its causes and prevention so as to reduce its occurrence. Researches on better ways to extract the active antimicrobial agents in plants and thus their introduction to the pharmaceutical industry should be encouraged so that they can be used in the production of newer, safer and possibly, cheaper drugs. It is therefore strongly believed that the gains from the above practice would certainly underpin possible health outcome and also collectively reduce the increasing trend of multi drug resistance problems across the globe. However, it is the scholar's opinion that more novel research in this direction should be encouraged and should also be strongly sustained for the benefit of man across the globe especially in our developing communities.

\section{Conflict of Interest}

None was reported among authors.

\section{Acknowledgement}

The authors are sincerely grateful to $\mathrm{Dr}$ Azuonwu, Good luck, Joy Benson Brown and Enwereji Hope for their increasing support and prayers at all time.

\section{References}

1. Nester EW, Anderson DG, Roberts CE, Pearsall NN, Nester, MT (2004) Microscopy and cell structure, application of immune responses, wound infections. In: Microbiology: A human perspective. (4th edn), New York: McGraw-Hill, USA. pp. 468-698.

2. Grenet K, Guillemot D, Jarlier V, Moteau B, Dubourdier S, et al. (2004) Antibacterial resistance, Wayampis Amerindians, French Guyana. Eerg. Infect Dis 10: 1150-1153.

3. Muhammad HS, Muhammad S (2005) The antibacterial properties of Passiflora foetida L- A common exotic medicinal plant. Afr J Biotechnol 6: 2650-26534.

4. Pfaller MA, Jones RN, Biedenbach A (2001) Antimicrobial resistance treands in medical centres using carbanens, report of 1999 and 2000 results from the MYSTIC Programme (USA). Diagn Microbiol and Infectious Dis 41: 177-182.

5. Akinyemi KO, Oladapo O, Okwara CE, Ibe CC, Fasure KA (2005) Screening of crude extracts of six medicinal plants used in South-West Nigeria unorthodox medicine antimethicilin resistant Staphlococcus aureus Activity. BMC Complement Altern Med. 5: 1-7

6. Kavase M, Motohashi N, Sakagami H, Kanamoto T, Nakashima T, et al. (2001). Antimicrobial Activity of trifluoromethyl ketones and their synergism with promethazine. Int J Antimicrob Agents. 18: 161-165.

7. Tenover FC (2001) Development and spread of bacterial resistance to antimicrobial agents. An overview. Clinical infect Dis. 33: 5108-5115.

8. Niccoli DL, Tarsi L, Thomas RJ (2001) The renewed challenges of antibacterial chemotherapy. Chem Commun 42: 2333-2342.

9. Orrett FA (2002) Nosocomial infections in an intensive care and in a private hospital. West Indian Med J 51: 21-24.

10. Pretorius JC, Magama S, Zietsman DC (2003) Growth inhibition of plant pathogenic bacteria and fungi by extracts from selected South African plant species. S Afr J Bot. 20: 188-192.

11. Okwori AE, Dina GO, Junaid S, Okeke IO, Adetunji JA (2007) Antibacterial activities of ageratum conyzoides extracts on selected bacterial pathogens. Internet J Microbiol 4: 1-16.

12. Akinyeye AJ, Solanke EO, Adebiyi IO (2014) Phytochemical and antimicrobial evaluation of leaf and seed of Moringa oleifera extracts. Int J Res Med Sci 4: 1

13. Igbinosa OO, Igbinosa EO, Aiyegoro OA (2009) Antimicrobial activity and phytochemical screening of stem bark extracts from Jatropha curcas (Linn). Afr J Pha Pharmacol 3: 58-62.

14. Ayoola GA, Coker HAB, Adesegun SA, Adepoju-Bello AA, Ezennia OK, et al. (2008). Phytochemical screening and antioxidant activities of some selected medicinal plants used for malaria therapy in Southwestern Nigeria. Trop J Pharm Res 7: 1019-1024.

15. Sreelatha S, Padma P (2010) Antioxidant activity and total phenolic content of Moringa olifera leaves in two stages of maturity. Plant Foods Hum Nutr 64: 303-311.

16. Nagaratna A, Prakash LH (2015). A comprehensive review on Parnabeeja (Bryophyllum pinnatum (lam.) Oken). J med plants stud 3: 166-171.

17. Ghasi S, Egwuibe C, Achukwu PU, Onyeanusi JC (2011) Assessment of the medical benefit in the folkloric use of Bryophyllum Pinnatum leaf among the Igbos of Nigeria for the treatment of hypertension. Afr J Pharm Pharmacol 5: 83-92.

18. Faleye FJ, Ogundaini OA (2012) Evaluation of antioxidant and antimicrobial activities if two isolates from Aspilia africana (pers) C.D. Adams. ${ }^{\text {IRJP }}$. 3: 135-138. 
19. Page JE, Balza F, Nishida T, Towers GHM (1992) Biologically active diterpenes from Aspilia mossambiecensis- a chimpanzees medicinal plant. Phytochemistry 31: 3437-3439.

20. Okoli CO, Akah PA, Nwafor SV, Anisiobi Al, Ibegunam IN, et al. (2007) Anti-inflammatory activity of hexane leaf extract of Aspilia Africana (Pers) C.D. Adams. J Ethnopharmacol 109: 219-225.

21. Nguelefack TB, Watcho P, Sulvie LW, Ngetla MM, Dieudonne N, et al. (2005) The antiulcer effects of the methanol extract of the leaves of Aspilia Africana (Asteraceae) in rats. Afr J Traditional 2: 233-237.

22. Cheesbrough $M$ (2006) District laboratory practice in tropical countries. Part 2. Cambridge University Press, UK. pp. 143-157.

23. Girish HV, Satish S (2000) Antibacterial activity of important medicinal plants on phytopathogenic Xanthomonas compestris Pathovars. Lett Microbiol 28: 145-147.

24. Ekpe ED, Ebana RVB, Madunagu BE (1990) Antimicrobial activity of four medicinal plants on pathogenic bacteria and phytopathogenic fungi. West African Journal of Biology and Applied Chemistry 1: 23-25.

25. Atata R, Sani A, Ajewole SM (2003) Effect of stem back extracts of Enantia chloranta on some clinical isolates. Biokemistri 15: 84-92.
26. Hsueh IP, Lin JH, Jeng JS, Hsieh CL (2002) Comparison of the psychometric characteristics of the functional independence measure, 5 item Barthel Index, and 10 item Barthel Index in patients with stroke. J Neurol Neurosurg Psychiatry 73: 188-90.

27. Brooks GF, Butel JS, Morse SA (2003) Cell Structure: In: Jawets, Melnick and Adelberg's medical microbiology (22nd edn). Lange Medical Books/McGraw-Hill, USA. Pp. 7- 37.

28. Vatopoulos AC, Kalapothaki V, Legakis NJ (1999) Bacterial resistance to ciprofloxacin in Greece: Results from the national electronic surveillance system. Greek Network for the surveillance of antimicrobial resistance. Emerg Infect Dis 5: 471-476.

29. Obi VI, Onuoha C (2000) Extraction and characterization methods of plants and plants products. In: Biological and agricultural techniques. Ogbulie JN, Ojaiko OA (eds). Websmedia publishers, Owerri, Nigeria. pp. 271-286.

30. Okwu DE, Josiah C (2006) Evaluation of the chemical composition of two Nigerian medicinal plants. Afr J Biotechnol 5: 257-361.

31. Oluyemi KA, Omotuyi IO, Jimoh OR, Adesanya OA, Saalu CL, et al. (2007) Erythropoietic and anti-obesity effects of Garcinia cambogia (Bitter kola) in Wistar Rats. Biotechnol Appl Biochem 46: 69-72. 